\title{
Do COGNITIVE TeSt SCORES EXPLAIN Higher \\ U.S. WAGE INEQUALITY?
}

\author{
Francine D. Blau \\ Cornell University, NBER and CESifo \\ and \\ Lawrence M. Kahn \\ Cornell University and CESifo
}

Forthcoming: The Review of Economics and Statistics

*The authors thank Abhijay Prakash and André Souza for excellent research assistance. This paper has benefited from the comments and suggestions of Daron Acemoglu, Gordon Dahl, Henry Farber, Andrea Ichino, Michael Wallerstein and two anonymous referees, and from seminar participants at the NBER Labor Studies Conference, the Cornell-Princeton Conference on Labor Markets in Comparative Perspective, the Cornell University Institute for European Studies Workshop on Comparative Political Economy of Inequality in OECD Countries, the CESifo Area Conference on Employment and Social Protection, the University of Houston, University of Rochester, University of Texas, Michigan State University and Syracuse University. Portions of this paper were written while the authors were Visiting Scholars at the Russell Sage Foundation; we gratefully acknowledge this support. 


\title{
Do Cognitive Test Scores EXPlain Higher U.S. WAge INEQUALITY?
}

\begin{abstract}
Using microdata from the 1994-8 International Adult Literacy Survey (IALS) for nine countries, we examine the role of cognitive skills in explaining higher wage inequality in the United States. We find that while the greater dispersion of cognitive test scores in the United States plays a part in explaining higher U.S. wage inequality, higher labor market prices (i.e., higher returns to measured human capital and cognitive performance) and greater residual inequality still play important roles, and are, on average, quantitatively considerably more important than differences in the distribution of test scores in explaining higher U.S. wage inequality. JEL category $\mathrm{J} 31$.
\end{abstract}




\section{Introduction}

Considerable evidence indicates that wage inequality is substantially higher in the United States than in other OECD countries. A growing body of comparative labor market research has attempted to explain this higher level of wage inequality, focusing particularly on the role of market forces and international differences in labor market institutions. ${ }^{1}$ Explanations emphasizing market forces focus on supply and demand, pointing to a larger relative supply of less skilled workers in the United States. Institutional explanations hypothesize that institutions such as collective bargaining, unemployment insurance (UI), and job protection regulations compress wage differentials at the bottom of the distribution in the other OECD countries compared to the United States. A central requirement of either of these two explanations is that higher labor market prices in the United States be important in explaining higher U.S. wage inequality. While this may be the case, economists have also recognized that differences in population heterogeneity across countries can produce varying levels of wage inequality.

Most previous attempts to disentangle the effects of population heterogeneity and labor market prices on wage inequality have used micro-data that allowed controls for levels of schooling and age or actual labor market experience (e.g., Blau and Kahn 1996; Kahn 2000), generally concluding that both prices and population heterogeneity play a role. However, labor market skills may differ even among workers with the same years of schooling and age or experience. In particular, it is believed that school systems in Continental Europe produce a more uniform level of cognitive skills than the highly decentralized United States system. Supporting this view are the results of recently available international comparisons of performance on the same tests from the International Adult Literacy Survey (IALS), which show much lower relative and absolute performance in the United States among those with little education than in the rest of the OECD (OECD 1998; Nickell and Bell 1996; Nickell and Layard 1999). If these tests measure skills that are useful in the labor market, the evidence on test scores

\footnotetext{
${ }^{1}$ For reviews, see Blau and Kahn (1999 and 2002).
} 
could provide an alternative to the view that higher returns to skills in the United States are important in explaining its higher level of wage inequality. Rather this heretofore unmeasured heterogeneity in cognitive skills might be sufficient to account for higher U.S. wage inequality. Nickell and Layard (1999) in fact make such an argument with respect to the higher returns to education observed in some countries. Using aggregate IALS data from six countries, they show that wage differentials by education groups are positively related to test score differentials across the same education groups. In particular, the United States had the highest wage and test score differentials by education. While this suggests that cognitive skills play a role in explaining higher U.S. wage inequality, in the absence of more detailed analyses, it is not possible to know how important this role is.

The purpose of this paper is to determine how much of the higher U.S. wage dispersion is explained by the distribution of cognitive ability. We use microdata from the 1994-98 IALS for nine countries. In addition to the traditional human capital measures of schooling and age, the IALS contains the results of comparable cognitive tests administered in a number of countries in the areas of arithmetic operations, prose literacy, and document-reading ability, making it an excellent source of data to address this question.

\section{Previous Findings on the Role of Prices in Explaining Higher U.S. Wage Inequality}

In earlier work using microdata from the International Social Survey Programme (ISSP) on ten countries for the mid- to late-1980s, we found that the considerably higher levels of male wage inequality in the United States primarily reflected substantially more compression at the bottom of the wage distribution in these other countries and, while differences in measured characteristics of workers explained some of this pattern, higher U.S. prices or higher rewards to skills in the United States were an important factor (Blau and Kahn 1996). We presented a variety of evidence that labor market institutions were the most likely explanation for the observed differences between the United States and the other countries, including the fact that the observed pattern of inequality was consistent with a role for unions in "bringing up the 
bottom" of the wage distribution. In contrast, we found that international variation in supply and demand measures based on skill indexes constructed using data on education and potential experience (the skill measures available in the ISSP) did not move in the right direction for market forces to provide a viable explanation for the observed patterns.

This research did not take account of cognitive skills due to lack of data. Yet, a voluminous literature, primarily from the United States, documents the strong impact of cognitive ability, as measured by standardized test scores, on wages, even after controlling for education and age-related proxies for experience. ${ }^{2}$ Thus, the issue arises as to whether these conclusions would hold up when this factor is taken into account. In particular, the questions we focus on in this paper are whether labor market prices are indeed higher in the United States than elsewhere and whether they continue to explain a substantial share of higher wage inequality in the United States when cognitive skills are taken into account.

Two recent studies are particularly relevant since they use the IALS microdata and thus shed light on the importance of cognitive skills in explaining higher U.S. wage inequality. First, Freeman and Schettkat (2000) studied the determinants of individuals' after tax personal incomes and found that the United States has higher returns to education and test scores than Germany, as well as higher residual income inequality. Our own study extends this work to examine the impact of cognitive skills in a more comprehensive fashion. We examine eight countries other than the United States and provide a full accounting of the impact of cognitive skills, other human capital characteristics and labor market prices on wage inequality in the United States compared to other countries. ${ }^{3}$

Second, Leuven, Oosterbeek and van Ophem (forthcoming), using an approach similar to the supply and demand component of Blau and Kahn (1996), focus on the potential role of market forces in explaining wage differentials between men with low-, middle- and high skills.

\footnotetext{
${ }^{2}$ See, for example, Cawley, Coneely, Heckman, and Vytlacil (1996), Neal and Johnson (1996), and Bishop (1991).

3 After we wrote the first draft of this paper, Devroye and Freeman (2001) produced an analysis of the IALS microdata using different methodology that reaches similar broad conclusions to ours. Unlike their variance decomposition technique, our decompositon allows one to examine different portions of the wage distribution separately.
} 
Similar to Blau and Kahn (1996), they find no evidence that wage differentials by skill are related to international differences in supply and demand when skill is measured by education and potential experience. However, when skill is measured by cognitive tests - their preferred measure due to greater international comparability - more evidence of consistency with supply and demand is obtained, especially in explaining the relative wages of low skilled workers. Overall, they find that about one third of the variation across countries in relative wages by skill is explained by differences in net supply (i.e., supply adjusted for demand). Our results presented below are relevant in suggesting some caution in basing conclusions solely on one measure of skills, regardless of international comparability. Specifically our findings are consistent with cognitive skills and education measuring different though overlapping skills. Nonetheless, the Leuven, Oosterbeek and van Ophem results suggest that a consideration of cognitive skills puts supply and demand back "on the table" as an explanation for differences in returns to at least one dimension of skills, while, as the authors acknowledge, leaving the door open to institutional factors also explaining a portion of the international variation.

\section{Empirical Analysis}

\section{A. Data and Methods}

The International Adult Literacy Survey (IALS) is the result of an international cooperative effort, conducted over the 1994-8 period, to compare the cognitive skills of adults across a number of countries. ${ }^{4}$ The sampling frame was similar across countries, with the target population being those 16 years and older who were not in institutions or the military. In addition to test scores, data are available on variables generally included in wage analyses and, for a subset of countries, earnings. Among that group, we focus on the advanced economies and exclude the transition economies of Eastern Europe; the included countries are Canada,

\footnotetext{
${ }^{4}$ For further description of the IALS, see OECD (1998) and USDOE, NCES (1998). We obtained the IALS data from Statistics Canada. The IALS supplied a set of sampling weights, which we used in all of our analyses.
} 
Denmark, Finland, Italy, the Netherlands, Norway, Sweden, Switzerland, and the United States. ${ }^{5}$

Of unique interest in the IALS is its measurement of cognitive skills. This was

accomplished through three tests that were administered to all respondents in the language of their country of residence (or, in the cases of Switzerland and Canada, the region of their country of residence). These tests were designed to measure: “a) Prose literacy — the knowledge and skills needed to understand and use information from texts including editorials, news stories, poems and fiction; b) Document literacy — the knowledge and skills required to locate and use information contained in various formats, including job applications, payroll forms, transportation schedules, maps, tables, and graphics; and c) Quantitative literacy — the knowledge and skills required to apply arithmetic operations, either alone or sequentially, to numbers embedded in printed materials, such as balancing a checkbook, calculating a tip, completing an order form, or determining the amount of interest on a loan from an advertisement" (IALS Guide CD-ROM, page 15).

The IALS provides five alternative estimates of proficiency for each test, scored on a scale of $0-500$. We found that within each of the three types of test, the five estimates of the score were correlated at .86-.96. Further, although, in principle, interpreting prose or documents, and conducting arithmetic operations may each require different skills, we found that these skills, as measured by the IALS, are in fact highly correlated: averaging the five available estimates for each of the three tests (i.e., quantitative, prose, and document literacy), the resulting scores were correlated at between .88-.96. Due to this high correlation, in the econometric work that follows, we report results based on a measure of cognitive skills that is an average of the three average test scores for each individual test; however, we also estimated models with the three average test scores entered separately, with very similar results.

To analyze the sources of international differences in wage inequality, we use a fulldistributional accounting method, developed by Juhn, Murphy and Pierce (1993), that allows us

\footnotetext{
${ }^{5}$ Data on earnings were also available for Germany; we excluded Germany because, in our version of the IALS data, the sample size was extremely small for cases in which earnings data were available, East and West Germany were not distinguished, and the earnings distributions we obtained were not comparable to other sources.
} 
to decompose differences in wage inequality at any point of the wage distribution. This is potentially important in light of the presence of wage floors that mainly impact the bottom of the wage distribution and recent evidence from Leuven, Oosterbeek and van Ophem (forthcoming) that market forces do best at explaining relative wages of low skilled workers, with skill defined by cognitive test scores. Moreover, since we also used this approach in Blau and Kahn (1996), our use of it here provides comparability with that earlier study.

The Juhn, Murphy and Pierce accounting scheme involves constructing hypothetical wage distributions in order to partition international differences in wage inequality into three components: a measured characteristics effect due to differences in the distribution of measured characteristics of workers (i.e., observed worker heterogeneity); a wage coefficients effect due to differences in the rewards to measured characteristics; and a wage equation residual effect which is unexplained and potentially reflects the impact of unmeasured prices but which may also be due to differences in the distribution of unmeasured productivity characteristics (i.e., unobserved worker heterogeneity) and measurement errors. We take the wage coefficients effect and perhaps some portion of the wage equation residual effect as measures of the importance of labor market prices in explaining international differences in wage inequality. See Juhn, Murphy and Pierce (1993) and Blau and Kahn (1996) for details of this decomposition. ${ }^{6}$

To implement the Juhn, Murphy and Pierce decomposition, we estimate the following wage equations for individual $\mathrm{i}$ in country $\mathrm{j}$, estimated separately by sex among full-time workers:

$$
Y_{i j}=B_{j} X_{i j}+e_{i j}
$$

where $\mathrm{Y}$ is the natural log of weekly earnings, $\mathrm{X}$ is a vector of explanatory variables, $\mathrm{B}$ is a

\footnotetext{
${ }^{6}$ In the decompositions reported here, pair-wise comparisons between the United States and each of the other countries were implemented using the United States as the base for the personal characteristics distribution and the other country as the base for coefficients and residuals. However, results were similar when we used the opposite weighting scheme.
} 
vector of coefficients, and e is a disturbance term. In order to produce a wage measure that is as close as possible to an hourly earnings concept (i.e., price), we restricted the wage analysis to full-time workers; further, in order to produce a homogeneous sample of those with strong labor force commitment, we included only those who were employed at least 26 weeks in the previous year. Finally, we excluded those with measured weekly earnings less than the equivalent of U.S. $\$ 80$ (or for full time workers, less than about $\$ 2.00 / \mathrm{hr}$ at a time when the U.S. minimum wage was $\$ 4.25$ ) or more than U.S.\$10,000. ${ }^{7}$

The explanatory variables in $\mathrm{X}$ include educational attainment, age, and average IALS test score. Schooling is measured by number of years completed, and age is measured by a series of dummy variables for the following categories: $26-35,36-45,46-55$, and 56-65, with age 16-25 being the omitted category. We adopted this age specification because the IALS age data for Canada were only available in categorical form. ${ }^{8}$ In some analyses (not reported here), we include a vector of one-digit industry and occupation dummies. Including these variables might be considered desirable in order to control for differences across countries in occupation and industry mix in measuring the impact of labor market prices. However, explanatory variables such as test score and education may affect wages both directly, holding occupation and industry constant, and indirectly, through their effect on representation in higher-paying industries and occupations. Coefficients from regressions excluding industry and occupation variables thus shed light on the total effect of these variables. Moreover, if wage-setting institutions do in fact influence relative wages, the distribution of occupations and industries may also be affected. We thus focus on models excluding these variables, although the basic results

\footnotetext{
${ }^{7}$ Earnings data were topcoded for Switzerland (French and German speaking subsamples), and the Netherlands. For Switzerland, earnings data were collected for 1993 for the French and German subsamples with a 100,000 franc top code (about U.S.\$66,000) and for 1997 for the Swiss Italian subsample with no topcode. To produce a single Swiss sample, we first used the Swiss consumer price index, as reported on the BLS web site, to inflate the 1993 earnings figures to 1997. The topcoded value became 104,930 francs. We then took the average 1997 earnings in the Italian-speaking Swiss sample for those who earned at least 104,930 francs and assigned this value (132,903.1 francs) to everyone in the French and German subsamples who was at the top code. For the Netherlands, the topcoded value of 200,000 guilders (about U.S.\$105,000 in 1993) was multiplied by 1.2. Results were not sensitive to treatment of the topcoded values.

${ }^{8}$ Models using age and age squared where age was available (i.e. for countries other than Canada) yielded virtually identical results to the age dummy variable specification.
} 
were similar with industry and occupation included and are available upon request.

\section{B. Results: Basic Specification}

Before turning to the results of the decomposition, we first review the extent of international differences in wage inequality and cognitive test scores in the IALS data, as well as our findings for the effects of test score and education in the wage regressions estimated for each country. Figures 1 and 2 give summary information on male and female wage inequality across our sample of countries. Figure 1 shows that for men, wage inequality is higher at the bottom and the top in the United States than for the other countries, with a larger contrast for the 50-10 than for the 90-50 U.S.-other country comparisons. This basic pattern is consistent with our earlier work using male wage data for the 1980s (Blau and Kahn 1996). However, since then, inequality at the top has grown sharply in the United States (Topel 1997). Consistent with this trend, the IALS shows a greater U.S.-other country difference in wage inequality at the top of the wage distribution (90-50) than we found using the ISSP data for the 1980s. Figure 2 shows that wage inequality is also relatively high for U.S. women, and that the female 50-10 gap is especially high in the United States. Among women, however, Canada has greater inequality than the United States, a pattern also seen in OECD (1996) data.

Table 1 provides evidence on the distribution of cognitive test scores for men and women in the wage sample. A striking pattern is the higher level of test score inequality for both men and women in the United States than elsewhere: Americans do worse than the non-U.S. average at the bottom (about a 17 point deficit), about the same at the median, and better at the top (an 11-14 point advantage). The test score patterns for the wage sample roughly mirror the differences between the United States and other countries in wage distributions shown in Figures 1 and 2.

We next consider differences across countries in the impact of measured cognitive skills and education on wages. Table 2 shows the estimated effects of a one standard deviation increase in test scores or education on log wages, estimated from regressions controlling for both these variables as well as age. The standard deviations are computed on male (female) wage 
samples pooled across countries, where each country is given the same weight. ${ }^{9}$ The effects of education and test scores are highly significant in almost every case, and economically significant as well. For example, a one standard deviation increase in test scores raises wages by 5.3 to 15.9 percent for men and 0.7 to 16.2 percent for women, while a one standard deviation increase in education raises wages by 4.8 to 16.8 percent for men and 6.8 to 26.6 percent for women. ${ }^{10}$ Consistent with higher rewards to skills in general in the United States than elsewhere, U.S. men had the highest returns to test scores and education of the included countries (although the return to test score in the Netherlands was about the same as in the United States). Similarly, U.S. women had higher returns to education than women elsewhere, and their return to test score was higher than all but two of the other countries.

Our finding that, for both men and women, education is considerably more highly rewarded in United States than elsewhere, even controlling for test score, indicates that the greater dispersion of test scores in the United States does not fully account for its higher return to education. On the contrary, we find that the U.S. advantage in the return to education is fairly similar regardless of whether or not we control for test score. Specifically, for males (females), the U.S. return is $2.16(2.26)$ times higher than the average for the other countries when test scores are included compared to 2.51 (2.38) times higher when test scores are excluded (results available upon request).

Our findings are also of interest in suggesting that education and test scores measure different though overlapping skills. We find that the inclusion of test score lowers the estimated return to education by 43 percent for U.S. males and 27 percent for U.S. females; and on average for the other countries by 34 percent for males and 23 percent for females compared to regressions omitting test score (again, regression results available upon request). Thus, a significant part of the measured return to education in conventional human capital regressions is

\footnotetext{
9 That is, each individual is given a weight of $\mathrm{s} /\left(\mathrm{Ns}_{\mathrm{a}}\right)$, where $\mathrm{s}$ is the individual's sampling weight; $\mathrm{N}$ is his/her country's sample size; and $s_{\mathrm{a}}$ is his/her country's average sampling weight.

10 Statements about percentage effects are approximate, since they refer to the regression coefficients which are in $\log$ units.
} 
due to its effect on (or association with) cognitive skill. Nonetheless, our finding of positive and generally significant returns to both education and test scores in within country regressions including both variables suggests that each captures in part a unique dimension of skills. This impression is reinforced by the fact that, although the returns to education and cognitive skills are both usually higher in the United States than in the other countries, these returns are, in general, weakly correlated across countries. For example, regressing the education coefficients on the test score coefficients shown in Table 2, including a female dummy and correcting for heteroskedasticity and clustering within countries, yields an insignificant coefficient of $0.246 .{ }^{11}$ Applying the distinctions between types of skills suggested by Acemoglu (2002), a possible interpretation of these findings is that cognitive test scores reflect computational or reading ability and that, controlling for cognitive skills, formal schooling teaches teamwork.

The rewards to cognitive test scores and education may be weakly correlated across countries because the supply and demand for the distinct skill components they represent move differently across countries, or because of a differential impact of wage-setting institutions on the returns to formal qualifications versus cognitive skills, or some combination of both these factors. When we analyzed international differences in the education and test score coefficients, we found that, although they are weakly correlated across countries, they are both negatively related to the country's share of workers covered by collective bargaining as of 1994 (taken from OECD 1997). Specifically, regressions of the test score or education coefficient on a female dummy and collective bargaining coverage, correcting for heteroskedasticity and clustering within countries, yields a collective bargaining effect of $-0.00105(.00067)$ on the education coefficient and $-0.00086(.00027)$ on the test score coefficient. To put these point estimates into perspective, note that increasing collective bargaining coverage by 39 percentage points (the difference between Sweden's 89\% and Switzerland's 50\% coverage) is associated with a $.04 \log$ point lower return to a one standard deviation increase in education. This is equivalent to a

\footnotetext{
${ }^{11}$ We did not take into account the sampling errors associated with the main explanatory variable (the test score coefficient) which would be expected to further increase estimated standard errors (Murphy and Topel, 1985).
} 
$0.011 \log$ point reduction in the return to a year of schooling, a large effect compared to the average return to a year of school (controlling for test score and age) of 0.031 log points in the sample. The corresponding effect of a 39 percentage increase in collective bargaining coverage on the return to test scores is a $0.0007 \log$ point reduction in the return to a one point increase in test score, a large effect compared to the average test score effect in our sample of 0.0018 . These results are consistent with a role for institutions in explaining the international differences, although they do not rule out supply and demand as also playing a part.

While the descriptive data on wages and test scores suggest that cognitive skill plays a part in explaining the higher level of wage inequality in the United States, a more systematic analysis is needed to establish its precise importance. The results shown in Table 3 enable us to assess the effect of differences in the distribution of characteristics, measured labor market prices and residual inequality in explaining higher U.S. wage inequality, and to ascertain the marginal effect of including test scores in the standard human capital specification (results for individual countries are available upon request). Specifically, Table 3 presents summary decomposition results (i.e., average effects) from alternative specifications of the wage equation where the explanatory variables include: i) age and test score; ii) age and education; and iii) age, education and test score. The marginal effect of test scores in explaining the higher level of U.S. wage inequality (given in column 3 ) is computed as the difference between the measured characteristics effect with and without test score in the indicated model. Of course, the inclusion of test scores can also affect the magnitude of the wage coefficients and residual effects, and we also discuss these impacts below.

Each entry in Table 3 should be read as an average U.S.-other country difference. Thus, for example, the first entry in column 1 indicates that the male 50-10 wage gap is .309 log points higher in the United States than the unweighted average for the other countries. As may be seen in the Table, wage coefficients and residual effects are positive, on average, across all three specifications. Measured characteristics effects are positive for the male and female 50-10 gap and for the female 90-50 gap, and negative for the male 90-50 gap. The marginal effects for test 
score are positive, indicating that the inclusion of test scores in the wage equation raises the measured characteristics effect. Of particular interest is the impact of adding test score to the traditional human capital equation which includes controls for age and education: the inclusion of test score raises the average measured characteristics effects by .007 to .048 log points. Thus, the estimated contribution of the distribution of test scores to explaining higher U.S. inequality ranges from 3 to 13 percent of the U.S.-other country differential, on average.

While the U.S. distribution of test scores helps to explain the higher level of U.S. wage inequality, the results indicate that higher measured U.S. prices are far more important, accounting for 28 to 55 percent of the difference in inequality between the United States and other countries (in the specification including age, education and test score). The average wage coefficients effect is found to be substantially larger than the marginal effect of test scores under both specifications which include test score - ranging from .054 to .109 log points larger. And, the average coefficient and residual effects taken together exceed the marginal effect of the distribution of test scores by .168 to .248 log points. These results suggest that labor market prices are quantitatively more important than the distribution of cognitive ability in explaining the higher level of wage inequality in the United States. Including cognitive ability in the model necessarily reduces the sum of the wage coefficients and wage equation residuals effects by the same amount that it increases the measured characteristics effect. Thus, if we consider the sum of the wage coefficients and wage equation residual effects to be the potential effect of labor market prices, failure to include test scores results in an overstatement of this effect by a modest $3.1 \%-16.2 \%$ of the true price effect.

Table 3 indicates that labor market prices are higher in the less-unionized United States than in the more-unionized other countries. We also examined whether this relationship holds more generally. Specifically, we regressed a country's 50-10 or 90-50 coefficients effect, residual effect, and their sum separately on a female dummy variable and the country's collective bargaining coverage (correcting the standard errors for heteroskedasticity and clustering within countries). In all six cases, collective bargaining coverage had a positive, economically sizable 
and highly significant effect (at better than the $1 \%$ level on two tailed tests) on the U.S.-other country difference. $^{12}$ These effects were all slightly larger for the 50-10 than for the 90-50 gap. Again, a role for institutions is suggested, although supply and demand cannot be ruled out as an additional explanatory factor.

\section{Results: Robustness Checks}

The basic results in Table 3 indicate that labor market prices are higher in the United States than elsewhere. We now examine a number of robustness checks to these basic results. One issue to be considered is sample selectivity. Employment-to-population ratios are usually higher in the United States than in other countries (Blau and Kahn 1999 and 2002). It is possible that U.S. wage inequality appears to be higher because we observe a larger portion of the bottom of the queue of workers in the United States than in other countries in which a smaller percentage of the population is employed.

We investigated these issues using three different methods of adjusting for sample selectivity in each case adopting as our basic specification the third presented in Table 3, i.e., including age, education and test score as explanatory variables. The first method involved repeating the analysis for a sample restricted to males aged 26-55 with the rationale that this group is most firmly attached to the labor force in each country. The findings for this group were quite similar to those presented in Table 3 for a broader age range.

The second method again repeated the analysis for men, and this time for women as well, but now excluded portions of the sample in order to base intercountry comparisons on similarlyselected subsamples of the population, similar to a technique used by Hunt (2002). To determine the wage sample, we first computed a predicted probability of being in the wage sample for each U.S. male (female) in the population based on a probit model for U.S. men (women) in which the

12 The collective bargaining coefficients for the wage coefficients effect were .0019 (.0004) for the 50-10 gap and .0014 (.0004) for the 90-50 gap; for the residual effect, .0023 (.0005) for the 50-10 gap and .0016 (.0003) for the 90-50 gap; and for the sum of the wage coefficients and residual effect, .0042 (.0006) for the 50-10 gap and.0030 (.0007) for the 90-50 gap. To illustrate the magnitude of these effects, a 39 percentage point increase in collective bargaining coverage (as noted earlier, the Sweden-Switzerland difference) lowers the 50-10 wage coefficients effect by $0.074 \log$ points, a sizable estimate compared to the average effect of $0.112 \log$ points. 
probability of being in the wage sample is a function of age dummies, education and test score. We then excluded from the original U.S. wage samples those with the lowest predicted probabilities of inclusion until the U.S. wage sample reflected the same share of the population as in the comparison country. ${ }^{13}$ This procedure provides some adjustment for selectivity bias both in our estimate of overall wage inequality and our estimation of the wage equation itself. A drawback is that we do not analyze the full distribution of wage offers for the full population. Rather, we compare subsets of the population with similar probabilities of being in the wage sample. We find that wage coefficients and residuals effects in these models are positive and similar in magnitude to those from the uncorrected samples.

The third method, similar to Neal and Johnson (1996), uses median regression to estimate the determinants of conditional median wage offers assuming that those out of the wage sample had below median wage offers; we assign the minimum cutoff of US $\$ 80$ per week for this group. If more than half of the population is out of the wage sample, or if some of this group has (unobserved) wage offers greater than the population median, then we will not be able observe the population median, and this method will give misleading results. Since for most of the countries less than half of women and less than half of men age 16-25 or age 56-65 were included in the wage sample, we applied this approach only to men age 26-55. Median regression allows us to estimate the determinants of the conditional median of the log of wages. Since, under some circumstances, median regression is a good estimate of the conditional mean (Koenker and Bassett 1978), we used the median regression coefficients from each country's regression to compute a predicted wage for each U.S. man in the population and compared the resulting predicted wage distributions. Again, higher labor market prices in the United States were indicated.

Another set of issues relates to international differences in population diversity. First, it is possible that a given test score may not mean the same for an immigrant as it does for a native,

\footnotetext{
13 In two cases - Swiss men and Finnish women - the sample inclusion probability was higher than in the U.S., leading us to truncate these two country-gender samples instead.
} 
given differences in language ability and that countries differ in the size and composition of their immigrant populations. To address these concerns, we re-estimated our models for natives only. We found that the estimated U.S.-other country differences in wage inequality tend to be smaller when we compare natives in both countries, especially among men. However, the results of the decomposition were quite similar to those obtained for the full population. Moreover, it is interesting to note that test scores among natives in the United States at the bottom of the distribution were much more similar to those in the other countries than among the whole population (including immigrants). Second, given the well-known racial differentials in wages and employment in the United States, particularly for men (e.g., Altonji and Blank 1999), we reestimated all of our models using a subsample of non-Hispanic whites from the United States and the original samples from the other countries. ${ }^{14}$ Our findings were again similar to those reported in Table 3.

Finally, the functional forms on which the decompositions in Table 3 are based are relatively simple - including (as indicated) age dummies and separate linear terms for education and test score. We have also performed decompositions based on a model with full interactions between linear and quadratic education and test score terms (with main quadratic terms included as well). Our basic conclusions about higher U.S. labor market prices were robust with respect to this highly flexible alternative functional form.

\section{Conclusion}

This paper has used data from the International Adult Literacy Survey to examine the role of cognitive skill in explaining higher wage inequality in the United States. Using a fulldistributional accounting method devised by Juhn, Murphy and Pierce (1993), we find that while performance on cognitive tests plays a role in explaining greater U.S. wage inequality, higher labor market prices (i.e. higher returns to measured human capital and cognitive performance) and greater residual inequality still play important roles for both men and women. And we find

\footnotetext{
14 Information on race and ethnicity was not consistently available for the other countries.
} 
that, on average, prices are quantitatively considerably more important than differences in the distribution of test scores in explaining the relatively high levels of wage inequality in the United States.

Even if the United States does have higher prices of labor market skills, the explanation for this difference could rest either on institutions, such as collective bargaining, or market forces. The United States has much less coverage by collective bargaining than elsewhere in the OECD, but the United States also has a greater abundance of low-skilled workers when skill is defined by cognitive skills. Either feature of the U.S. labor market, or a combination of both, could produce higher skill prices. We found some evidence in support of the institutional explanation in that U.S.-other country difference in prices was positively significantly correlated with the country's collective bargaining coverage. Of course, this finding does not preclude a role for supply and demand as well. Moreover, the two may be related through feedback effects. Institutions may indirectly influence supply of or demand for labor. On the supply side, low wage premia for human capital investments due to institutional factors may deter individuals from making large human capital investments, thus yielding a smaller supply of high skilled workers. Alternatively, to the extent that wage compression results in youth unemployment, the opportunity cost to investing in a college education may be reduced, encouraging attendance. On the demand side, Acemoglu (2003) suggests that union-induced wage compression can cause firms to increase their demand for less-skilled workers by making techniques using less skilled labor more profitable. Union policies may also directly affect supply or demand for labor. For example, Summers, Gruber and Vergara (1993) argue that in heavily unionized, "corporatist" societies (i.e. where unions, management and government play an important role in coordinating wage-setting at the national level), social spending is likely to be higher than in less unionized countries. Thus, it is plausible that governments in highly unionized countries push for extensive, uniform national systems of education. At the same time, institutions may themselves be endogenous and affected by characteristics of the population, such as homogeneity, which also influence the relative supplies of various skill groups. 


\section{REFERENCES}

Altonji, Joseph and Rebecca Blank, "Race and Gender in the Labor Market," In Orley Ashenfelter and David Card (eds.), Handbook of Labor Economics Volume 3C (Amsterdam: North-Holland, 1999), 3143-3259.

Acemoglu, Daron, "Technical Change, Inequality, and the Labor Market, "Journal of Economic Literature," 40 (March 2002), 7-72.

Acemoglu, Daron, “Cross-Country Inequality Trends,” Economic Journal 113 (February 2003), F121-49.

Bishop, John H., "Achievement, Test Scores, and Relative Wages," in Marvin H. Kosters (ed.), Workers and Their Wages: Changing Patterns in the United States (Washington, DC: AEI Press, 1991), pp. 146-186.

Blau, Francine D. and Lawrence M. Kahn, "International Differences in Male Wage Inequality: Institutions Versus Market Forces," Journal of Political Economy 104 (August, 1996), 791-837.

Blau, Francine D. and Lawrence M. Kahn, "Institutions and Laws in the Labor Market," In Orley Ashenfelter and David Card (eds.), Handbook of Labor Economics Volume 3A (Amsterdam: North-Holland, 1999), 1399-1461.

Blau, Francine D. and Lawrence M. Kahn, At Home and Abroad: U.S. Labor Market Performance in International Perspective (New York: Russell Sage Foundation, 2002).

Cawley, John, Karen Coneely, James Heckman, and Edward Vytlacil, "Measuring the Effects of Cognitive Ability,” NBER Working Paper No. 5645, July 1996.

Devroye, Dan and Richard Freeman, "Does Inequality in Skills Explain Inequality of Earnings Across Advanced Countries?” NBER Working Paper No. 8140, February 2001.

Freeman, Richard and Ronald Schettkat, "Skill Compression, Wage Differentials and Employment: Germany vs. the US," NBER Working Paper 7610 (March 2000).

Hunt, Jennifer, "The Transition in East Germany: When is a Ten Point Fall in the Gender Wage Gap Bad News?" Journal of Labor Economics 20 (January 2002): 148-169.

Juhn, Chinhui, Murphy, Kevin M., and Pierce, Brooks, "Wage Inequality and the Rise in Returns to Skill,” Journal of Political Economy 101 (June, 1993), 410-442.

Kahn, Lawrence M., "Wage Inequality, Collective Bargaining and Relative Employment from 1985 to 1994: Evidence from Fifteen OECD Countries," The Review of Economics and Statistics 82 (November 2000): 564-579.

Koenker, Roger and Gilbert Bassett, “Regression Quantiles,” Econometrica 46 (January 1978): 
$33-50$.

Leuven, Edwin, Hessel Oosterbeek and Hans van Ophem, "Explaining International Differences in Male Inequality by Differences in Demand and Supply of Skill," Economic Journal, forthcoming.

Murphy, Kevin M., and Robert H. Topel, "Estimation and Inference in Two-Step Econometric Models," Journal of Business and Economic Statistics 3 (October 1985): 370-79.

Neal, Derek A. and William R. Johnson, "The Role of Premarket Factors in Black-White Wage Differences," Journal of Political Economy 104 (October, 1996), 869-895.

Nickell, Stephen and Brian Bell, "Changes in the Distribution of Wages and Unemployment in OECD Countries," American Economic Review 86 (May, 1996), 302-307.

Nickell, Stephen and Richard Layard, "Labor Market Institutions and Economic Performance," in O. Ashenfelter and D. Card (eds.), Handbook of Labor Economics Volume 3C (Amsterdam: North-Holland, 1999), 3029-3084.

OECD, Employment Outlook: July 1996 (Paris: OECD, 1996).

OECD, Employment Outlook: July 1997 (Paris: OECD, 1997).

OECD, Human Capital Investment: An International Comparison (Paris: OECD, 1998).

Summers, Lawrence, Jonathan Gruber and Rodrigo Vergara, "Taxation and the Structure of Labor Markets: The Case of Corporatism," Quarterly Journal of Economics 108 (May, 1993), 385-411.

Topel, Robert H., "Factor Proportions and Relative Wages: The Supply-Side Determinants of Wage Inequality," Journal of Economic Perspectives 11 (Spring 1997): 55-74.

U.S. Department of Education, National Center for Education Statistics (USDOE, NCES), Adult Literacy in OECD Countries: Technical Report on the First International Adult Literacy Survey, NCES 98-053 (Washington, DC: NCES, 1998). 
Figure 1: 50-10 and 90-50 Log Wage Differentials for Men

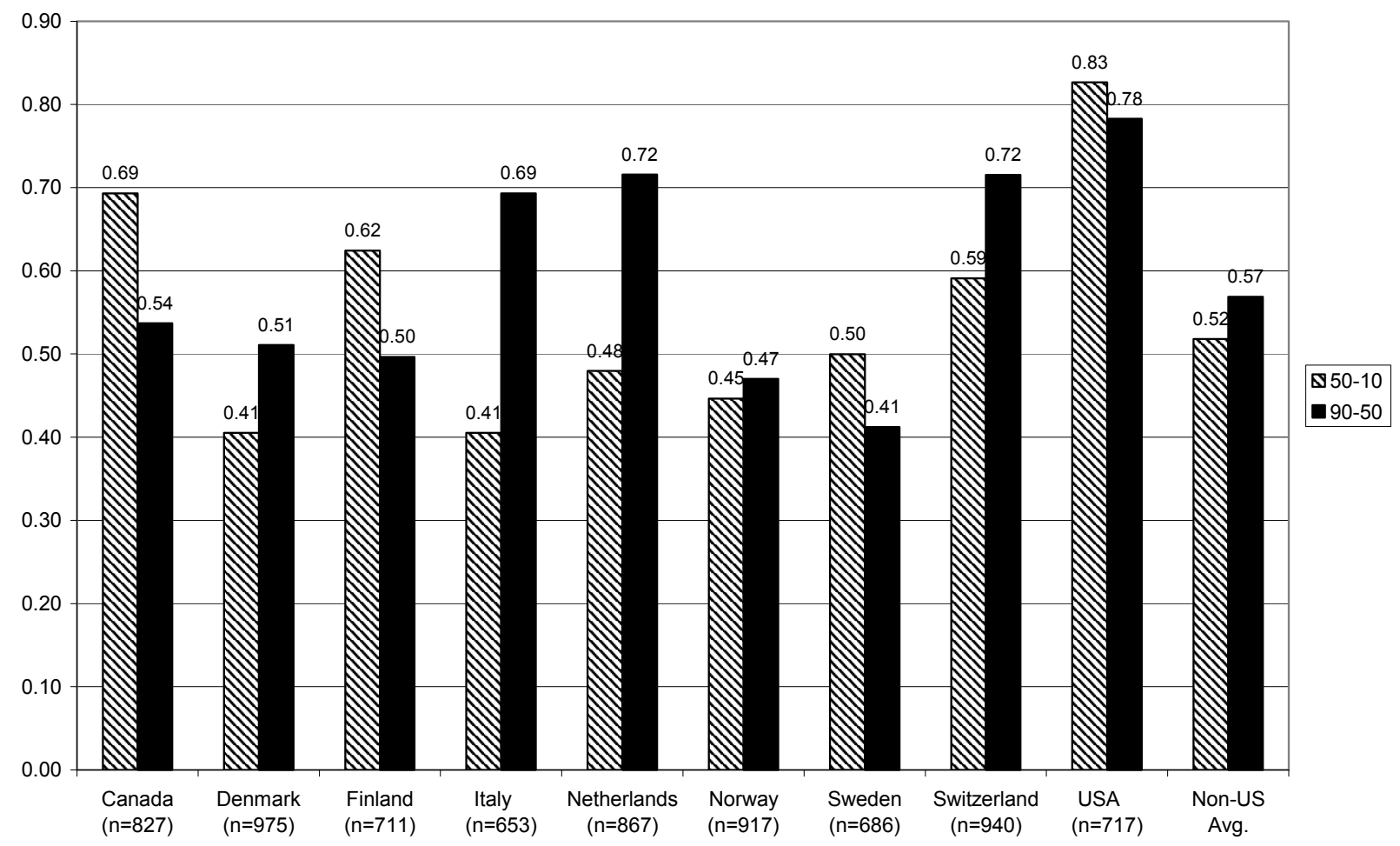


Figure 2: 50-10 and 90-50 Log Wage Differentials for Women

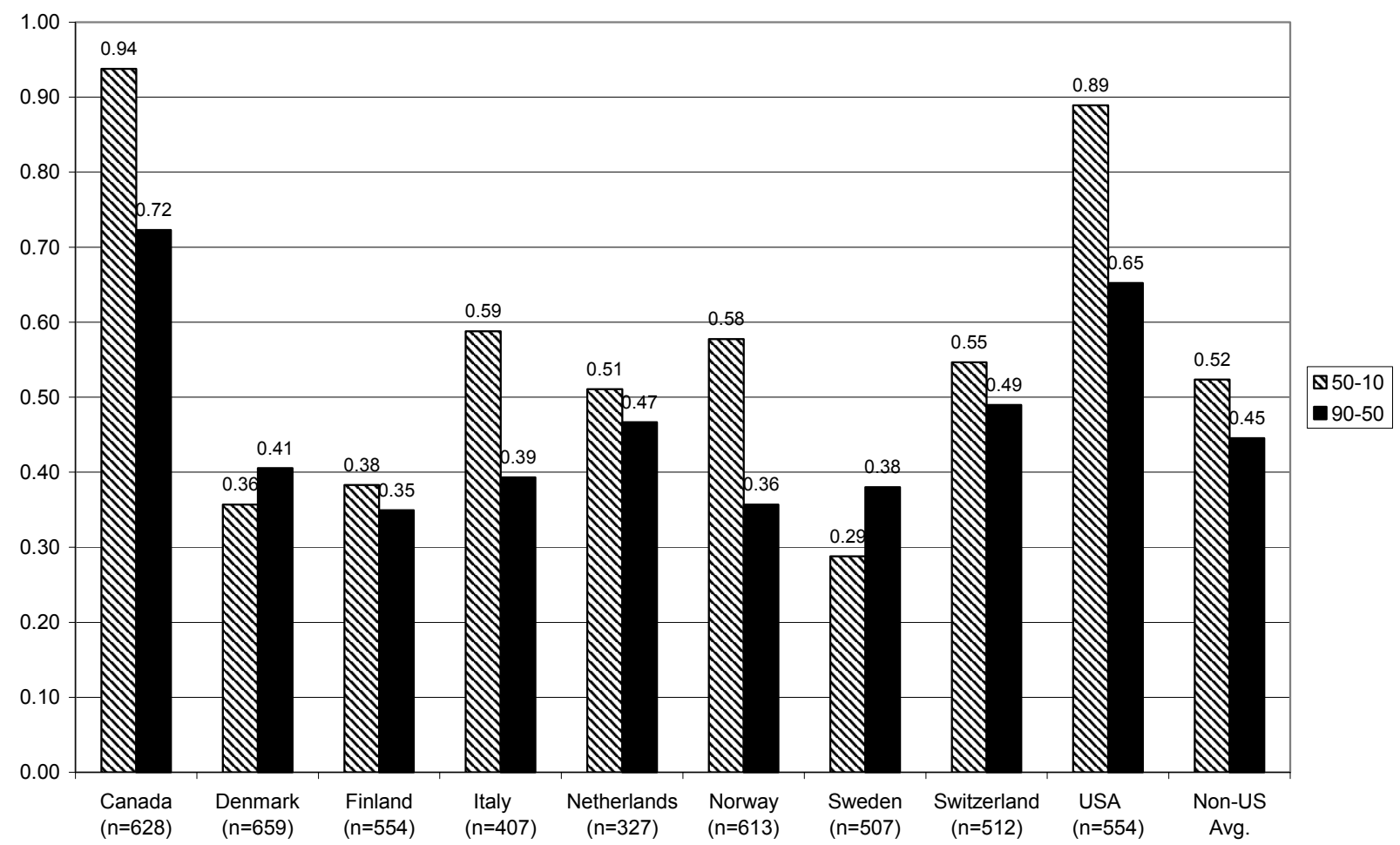


Table 1: Distribution of Individual Average Literacy Test Scores by Country and Gender

\begin{tabular}{|c|c|c|c|c|c|c|c|}
\hline \multirow[b]{2}{*}{ Country } & \multirow[b]{2}{*}{ Mean } & \multirow{2}{*}{$\begin{array}{c}\text { Standard } \\
\text { Deviation }\end{array}$} & \multicolumn{3}{|c|}{ Percentile } & \multicolumn{2}{|c|}{ Differential } \\
\hline & & & 10 & 50 & 90 & $50-10$ & $90-50$ \\
\hline \multicolumn{8}{|c|}{ Men } \\
\hline Canada & 295.96 & 52.40 & 233.95 & 296.76 & 362.29 & 62.81 & 65.53 \\
\hline Denmark & 296.44 & 38.00 & 248.91 & 300.35 & 339.27 & 51.44 & 38.92 \\
\hline Finland & 296.75 & 40.19 & 245.10 & 299.24 & 345.06 & 54.14 & 45.82 \\
\hline Italy & 251.86 & 56.58 & 172.52 & 261.26 & 313.74 & 88.74 & 52.48 \\
\hline Netherlands & 294.07 & 40.43 & 241.92 & 297.80 & 338.92 & 55.88 & 41.12 \\
\hline Norway & 300.09 & 38.62 & 246.64 & 304.59 & 344.60 & 57.96 & 40.00 \\
\hline Sweden & 311.60 & 46.37 & 256.31 & 313.94 & 365.97 & 57.63 & 52.03 \\
\hline Switzerland & 283.36 & 51.19 & 226.14 & 290.26 & 334.44 & 64.12 & 44.18 \\
\hline USA & 288.97 & 61.43 & 216.49 & 297.16 & 357.13 & 80.67 & 59.98 \\
\hline $\begin{array}{l}\text { Non-US } \\
\text { average }\end{array}$ & 291.27 & 45.47 & 233.94 & 295.53 & 343.04 & 61.59 & 47.51 \\
\hline \multicolumn{8}{|c|}{ Women } \\
\hline Canada & 299.11 & 56.19 & 225.92 & 307.46 & 365.08 & 81.53 & 57.62 \\
\hline Denmark & 292.86 & 35.01 & 242.10 & 298.15 & 334.64 & 56.05 & 36.49 \\
\hline Finland & 296.45 & 39.18 & 245.44 & 299.93 & 342.75 & 54.49 & 42.82 \\
\hline Italy & 259.75 & 50.31 & 191.97 & 267.04 & 316.36 & 75.07 & 49.32 \\
\hline Netherlands & 300.53 & 34.17 & 251.05 & 303.85 & 340.39 & 52.80 & 36.54 \\
\hline Norway & 306.02 & 37.51 & 257.87 & 309.20 & 349.56 & 51.33 & 40.36 \\
\hline Sweden & 308.54 & 43.08 & 259.48 & 310.49 & 361.42 & 51.02 & 50.93 \\
\hline Switzerland & 278.51 & 47.53 & 230.62 & 283.79 & 326.95 & 53.17 & 43.16 \\
\hline USA & 289.56 & 58.79 & 221.53 & 294.54 & 352.88 & 73.01 & 58.34 \\
\hline $\begin{array}{l}\text { Non-US } \\
\text { average }\end{array}$ & 292.72 & 42.87 & 238.06 & 297.49 & 342.14 & 59.43 & 44.66 \\
\hline
\end{tabular}

Note: Individual scores are the average of quantitative, document and prose test scores. Non-US average is the unweighted average of the figures in the Table. Sample includes only fulltime employed workers with at least 26 weeks' employment in the last year.

Source: International Adult Literacy Survey 
Table 2: Log Wage Effects of a 1 Standard Deviation Increase in Test Score or Education

\begin{tabular}{|c|c|c|c|c|}
\hline & \multicolumn{2}{|c|}{ Men } & \multicolumn{2}{|c|}{ Women } \\
\hline & Test Score & Education & Test Score & Education \\
\hline Canada & $\begin{array}{c}0.0900 \\
(0.0175)\end{array}$ & $\begin{array}{c}0.0884 \\
(0.0194)\end{array}$ & $\begin{array}{c}0.1615 \\
(0.0224)\end{array}$ & $\begin{array}{c}0.1497 \\
(0.0271)\end{array}$ \\
\hline Denmark & $\begin{array}{c}0.0719 \\
(0.0171)\end{array}$ & $\begin{array}{c}0.1113 \\
(0.0140)\end{array}$ & $\begin{array}{c}0.0777 \\
(0.0210)\end{array}$ & $\begin{array}{c}0.1130 \\
(0.0169)\end{array}$ \\
\hline Finland & $\begin{array}{c}0.0905 \\
(0.0248)\end{array}$ & $\begin{array}{c}0.0938 \\
(0.0202)\end{array}$ & $\begin{array}{c}0.0615 \\
(0.0202)\end{array}$ & $\begin{array}{c}0.1456 \\
(0.0157)\end{array}$ \\
\hline Italy & $\begin{array}{c}0.0531 \\
(0.0181)\end{array}$ & $\begin{array}{c}0.1039 \\
(0.0180)\end{array}$ & $\begin{array}{c}0.0597 \\
(0.0210)\end{array}$ & $\begin{array}{c}0.1310 \\
(0.0197)\end{array}$ \\
\hline Netherlands & $\begin{array}{c}0.1579 \\
(0.0188)\end{array}$ & $\begin{array}{c}0.0475 \\
(0.0126)\end{array}$ & $\begin{array}{c}0.1210 \\
(0.0325)\end{array}$ & $\begin{array}{c}0.0978 \\
(0.0217)\end{array}$ \\
\hline Norway & $\begin{array}{c}0.0975 \\
(0.0208)\end{array}$ & $\begin{array}{c}0.0539 \\
(0.0206)\end{array}$ & $\begin{array}{c}0.0074 \\
(0.0238)\end{array}$ & $\begin{array}{c}0.1403 \\
(0.0236)\end{array}$ \\
\hline Sweden & $\begin{array}{c}0.0734 \\
(0.0173)\end{array}$ & $\begin{array}{c}0.0603 \\
(0.0155)\end{array}$ & $\begin{array}{c}0.0321 \\
(0.0164)\end{array}$ & $\begin{array}{c}0.0990 \\
(0.0145)\end{array}$ \\
\hline Switzerland & $\begin{array}{c}0.0785 \\
(0.0216)\end{array}$ & $\begin{array}{c}0.0634 \\
(0.0247)\end{array}$ & $\begin{array}{c}0.0899 \\
(0.0273)\end{array}$ & $\begin{array}{c}0.0683 \\
(0.0292)\end{array}$ \\
\hline United States & $\begin{array}{c}0.1586 \\
(0.0194)\end{array}$ & $\begin{array}{c}0.1680 \\
(0.0256)\end{array}$ & $\begin{array}{c}0.1151 \\
(0.0211)\end{array}$ & $\begin{array}{c}0.2663 \\
(0.0318)\end{array}$ \\
\hline Non-US Average & 0.0891 & 0.0778 & 0.0763 & 0.1181 \\
\hline
\end{tabular}

Notes: Regressions include controls for test score, education and age dummies; standard errors are in parentheses. A one standard deviation increase in education is 3.5805 years; a one standard deviation increase in test scores is 49.4907 points. Standard deviations are calculated on the pooled weighted male and female wage samples giving each country the same weight. 
Table 3: Decomposition of US-Country J Differences in Wage Inequality: Average Effects for Alternative Specifications

\begin{tabular}{|c|c|c|c|c|c|}
\hline $\begin{array}{l}\text { Wage Equation } \\
\text { Specification }\end{array}$ & $\begin{array}{r}\text { US } \\
\text { Differential } \\
\text { - Country j } \\
\text { Differential }\end{array}$ & $\begin{array}{r}\text { Measured } \\
\text { Characteristic } \\
\text { s Effect } \\
\end{array}$ & $\begin{array}{r}\text { Marginal } \\
\text { Effect of Test } \\
\text { Scores } \\
\end{array}$ & $\begin{array}{r}\text { Wage } \\
\text { Coefficients } \\
\text { Effect }\end{array}$ & $\begin{array}{r}\text { Wage } \\
\text { Equation } \\
\text { Residual } \\
\text { Effect }\end{array}$ \\
\hline
\end{tabular}

A. Men: 50-10 Log Wage Differential

$\begin{array}{lllrrr}\text { Age and Test Score } & 0.309 & 0.111 & 0.030 & 0.110 & 0.088 \\ \text { Age and Education } & 0.309 & 0.091 & -- & 0.093 & 0.124 \\ \text { Age, Education, and } & & & & & \\ \text { Test Score } & 0.309 & 0.110 & 0.020 & 0.116 & 0.079\end{array}$

B. Men: 90-50 Log Wage Differential

Age and Test Score

Age and Education

Age, Education, and

Test Score

\section{Women: 50-10 Log Wage Differential}

Age and Test Score

Age and Education

Age, Education, and

Test Score

\section{Women: 90-50 Log Wage Differential}

Age and Test Score

Age and Education

Age, Education, and

Test Score
0.214

0.214

0.214

$-0.017$

$-0.048$

$-0.030$

0.018

0.013

$--$

0.070

0.149

0.161

0.113

0.138

0.106 